\title{
Increasing Students' Environmental Education and Awareness Through Campus Owned Waste Management Unit
}

\author{
Rachmat Mulyana $^{1}$, Eka Daryanto $^{2}$, Eko Wahyu Nugrahadi $^{3}$, Jubaidah $^{4}$, Rini Selly $^{5}$ \\ Pendidikan Teknik Bangunan Fakultas Teknik Universitas Negeri Medan ${ }^{1}$, \\ Pendidikan Teknik Mesin Fakultas Teknik Universitas Negeri Medan², \\ Pendidikan Ekonomi Fakultas Ekonomi Universitas Negeri Medan ${ }^{3}$, \\ Pendidikan Fisika FMIPA Universitas Negeri Medan ${ }^{4}$, \\ Pendidikan Kimia FMIPA Universitas Negeri Medan ${ }^{5}$ \\ [rachmat.mulyana10@gmail.com]
}

\begin{abstract}
Integrated Waste Management Center (P2ST) owned by State University of Medan was a program established by those who are committed in waste disposal, collection, and management. This program was part of Strategic Plan that principally included environmentally sound approach in its planning and implementation. Despite the support on environmental awareness through policies drafting and aid offering as this waste services, subsequent events such as technical advices and education session about waste system in order to encourage waste minimization practices based on re-use, recycling, and reduce, waste disposal and user choice to improve natural environment, have never been provided to students at undergraduate level. Therefore, students' visitation to this unit initiated to specifically educate them and improve their awareness since knowledge about waste management will decide their practices. The study was then conducted to understand knowledge and awareness limited only to waste and its management. A survey was done with a sample of 269 students visiting P2ST workshop from different faculties. A questionnaire consisted of both open-ended and close-ended questions were developed and pilot tested before given. The questionnaire consisted of two sections - first about personal information and second on their knowledge and awareness regarding waste system and management. Results showed that study participant had better awareness after visitation and become more conscious of composting, plastics waste recycling and reduction. Furthermore, a more practical implication related to the matter such as education about waste audits should be covered.
\end{abstract}

Keywords: Waste; Management; Education; composting

\section{Introduction}

The environment we live in is very important as it affects us directly. Even so, environmental problem has raised and resulted in such a global concern, in which around the world efforts are being made to make people aware about environmental protection. One of the main causes of environmental degradation is improper management waste. Waste is a major cause of pollution and outbreak of diseases in many parts of the world Proper management of the waste generated is most important in this matter. Waste management is a science that 
addresses the logistics, environmental impact, social responsibility and cost of an organizations' waste disposal. For example, in solid Waste Management (SWM), there were three basic components to consider including waste collection, transportation and disposal. Comprehensive waste management incorporates a diverse range of activities including reduction, recycling, segregation, modification, treatment and disposal that have varying levels of sophistication [1].

Thirty percent of the total 54 hectares area owned by Universitas Negeri Medan (Unimed), consist of open green space that also belongs to Medan city forest. Unimed consists of seven faculties with total number of 25,000 students, academic staff and employees. A calculation was made to estimate the number of waste this university generates within a single day. If one person produced $0.1 \mathrm{~kg} /$ day garbage and average plant litter was 2.5 ton / day trees, to sum it up about 5 ton / day or 6000 ton / year waste was created. In total, $75 \%$ of this waste is organic consisting of leaf, food scraps and paper waste, while the rests, $25 \%$ is inorganic waste such as plastic packaging, cans, glass bottles, etc. In addition to this, there is a considerable waste potential coming from other agencies and institution around Unimed campus.

Despite the apparent capacity, waste produced by Unimed and potential waste management has not been utilized properly until integrated waste management owned by this campus established in 2016. Before, trash after garbage collected is mostly transported and discharged to landfill located far outside the campus that is cost required. While others, such as leaves was collected and burned. It takes 24 hours more for the burning process to complete. The thickness of burnt garbage that lasted throughout the day often resulting in shortness of breath and eye irritation.

Waste management especially in one located specifically inside campus area is seen as a great potential that if used seriously can be a source of income generate. Good waste management in the campus environment can be used as an action and efforts to educate the environment to the campus community to realize Eco-campus, Green-Campus and Sustainable Development Campus. [1.2]

The impact of integrated solid waste management unit in Unimed (P2ST Great Unimed) is expected to create a clean and environmentally friendly campus area. This activity is expected to increase awareness and build environmentally friendly culture to all students, academics and surrounding community. One of expected Educational benefits brought by the formation of integrated waste management in Unimed is to provide an example for the community to participate in waste managing and to inform its activity so that more people becoming aware and taking interest in not only waste recycling but also managing.

\section{Method}

The study was carried out during students' visits to Campus owned integrated waste management unit (P2ST Great), in May 2017. It includes a study to a total of 269 participants form two different faculty, namely mathematics and natural sciences faculty (FMIPA) and faculty of engineering (FT). The type of study was experimental study. The data collection was done by a pretested, predesigned close-ended and open-ended questionnaire. Most of the questions had multiple-choice options, which made it easy for the respondents to answer them appropriately.

The open-ended question gave the respondents enough time and space to express their views. The open-ended questions were chosen to strengthening the close-ended questions and 
served to provide qualitative information to the study. The test consisted of 15 questions and was used to determine the knowledge (10 questions) and attitude (5 questions) toward 3R (reuse, reduce and recycle), hazardous waste, waste management, segregation and methods used for disposal, and potential economic value.

A brief talk was given to students about campus waste management, activities inside P2ST Great workshop and their doubts were solved after open and free discussion time was given. Each knowledge question has 1 point, while attitude questions is graded by using scale;1) 8 and more points was given to answers which considered as "good", 5 to 8 points as "moderate" and less than 5 points as "weak". Three experts and faculty members confirmed validity and reliability was confirmed in a pilot study with 30 students by Cronbach's alpha method as 0.77 .

The questionnaires were distributed among all students of each faculty twice, before briefing, sharing, and discussion session held and after informal lecturing. During the course of the study, informal interactions were also done with respondents to familiarize them with the objectives of the present study, their role and benefits to them from the study. Data was analyzed on a computer using SPSS (Statistical Package for Social Sciences) version 21.0. Descriptive statistics like percentage, mean, and SD (standard deviation) were computed for data presentation

\section{Result and Discussion}

The study sample consisted of 98 males and 171 females with the mean age of $20.4 \pm 6.3$ years. Total 102 students were studying biology education, 74 from chemistry education and 83 were engineering students. $92.4 \%$ of the students defined the recycling properly, $82.2 \%$ were aware of the importance of recycling after visitation session. The knowledge of students was the highest about the definition of recycling $(84.4 \%)$ and lowest about disposal and delivery of recycled materials (23.6\%). Most biology education (71.1\%) and chemistry education $(75.3 \%)$ students had "moderate" and most engineering students (69.1\%) had "moderate" knowledge about waste management after treatment. Further analysis showed that Most biology education (80.1\%) and chemistry education (80.9\%) students had "poor" and most engineering students (71.1\%) had "moderate" understanding and awareness about the connection of business which involve generating lots of trash. Students "were fairly unsure when asked about conducting a waste audit.

Regarding practice of proper waste management, students' participants showed they have proper idea and practice of waste segregation, conversion of waste to kitchen compost, in which biology education (61.1\%) and chemistry education (60.3\%) students had "moderate" and most engineering students $(69.1 \%)$ had "moderate" knowledge regarding these issues. Both groups were agreed that a full of commitment to minimize the wastes and to avoid throwing the wastes outside is seriously important.

Towards attitude, both groups have responded positively for minimizing the house holds waste $(\mathrm{p}>0.05)$ on post-test. Student who were came from either joint family or nuclear family showed equal percentage of awareness, practice and attitude toward issues directed to $3 \mathrm{R}$ (reuse, reduce and recycle), hazardous waste, waste management, segregation and methods used for disposal, and potential economic value of it.

A large amount of solid wastes is generated from homes. Household waste is major source of solid waste. The quantity of solid waste grows faster than population [4]. Solid waste disposal has been identified as a major cause of pollution and environmental threat globally. The findings 
of the present study have made it clear that they are well aware of the importance of waste management. But they are lacking in the practice of proper waste management. This study findings support the studies conducted by [5].

Moreover, a series of paired $t$ tests for within-group comparisons was used to determine if significant differences existed before and after visitation to P2ST Great Unimed. The results showed that there were statistically significant differences $(p<.05)$ before and after visitation and discussion session regarding students' knowledge and attitude toward waste management and its issues.

The results showed that in the beginning the number of correct answers given to the questions regarding to the awareness of recycling was good (60.2\%), but making the students becoming more aware of the knowledge about waste recycling program in P2ST workshop was show to give positive impact in increasing students' knowledge as much as $20 \%$. A study was conducted by Bagheri Ardabylyan \& Islami and to understand students' knowledge about similar issue. They have reported that more than $65 \%$ of the students are aware of recycling and suggested that in order to succeed in the recycling of solid waste, having an educational program using mass media can be an effective way to increase Knowledge and Attitude Level of Students about Solid Waste Recycling; awareness and public participation [6].

Tehrani, Hosseindoos, and Miranzadeh stated that students, family, media, newspaper and magazines, and schools and universities together could be the best way to acquire knowledge in the field of recycling [7]. There is a need for cooperation between these media, and the results are greater than ever and the mass media, e.g. television and radio, can have the greatest impact in this regard. Ehrampoush \& Moghadam [8] and Ugulu have mentioned that according to the students' opinion, the municipality should be in charge of the management of recycling in the society.

Students showed to highly agree that organizing workshops on solid waste management and recycling at the university level, presenting optional course with the theme of solid waste management in all academic fields, information given through brochures and pamphlets, holding competitions with the theme of waste recycling and management, and organizing a more scientific visitation would familiarize them with the problems of waste disposal and waste management. These are, according to students are among highly recommended acts to raise awareness of waste. There is no permanent solution for environmental problems, only thing we can reduce and control waste generation by proper awareness and practice.

An event like this helps to promote not any environmental and waste management awareness but also help students to realize the economic value as an outcome of P2ST activities. The Integrated Waste Management Unit of Medan State University (UNIMED) is a waste processing service to manage waste generated in UNIMED and surrounding campus environment. The long-term goal of this business unit is to open up opportunities for revenue generation for UNIMED and to create new entrepreneurs among lecturers and students, as well as waste management units. Organic waste will be processed into various types of fertilizer such as compost, liquid fertilizer, bokashi fertilizer, and kascing fertilizer.

Inorganic waste will be processed into creative products (Unimed merchandise), fuel, and block / paving block. This business unit will be managed using simple and efficient technology developed by the UNIMED Mechanical Engineering Study Program so that it will produce economically and ecologically useful products. The first-year results, P2ST managed to process organic waste into compost fertilizer, with a production amount of 5 tons / month. While the inorganic waste processed into creative products, about 500 pieces / month. The second year's special target is to improve product and product innovation. The production of compost fertilizer is increased about 10 tons / month, while the inorganic waste will be processed into creative 
product (merchandise Unimed) about 2.000 pieces / month, plastic count (1.4 tons / month), BBM (245 liter / month). Innovation in the second year is making product innovation that comes from organic waste is bokashi fertilizer $(1500 \mathrm{~kg} /$ month) and fertilizer kascing (1000 kg / month) and liquid fertilizer (1450 liter / month). In addition to product innovation, in the second year also targeted the expansion and improvement of marketing. The third year's special target is to increase production and expand marketing.

\section{Acknowledgment}

We are thankful to Dean, School of Universitas Negeri Medan, Medan, Sumatera Utara for giving us support in carrying out the study.

\section{References}

[1] Zagozewski, R., Judd - Henry, I., Nilson, S., and Bharadwaj, L. Perspectives of past and presentwaste disposal practices: A community based participatory research project in three Saskatchewan first nations communities. J. (2011)

[2] Environmental Health Insights, 5, pp. 9-20. International NGO Forum on Indonesian Development, Dokumen Hasil Tujuan Pembangunan Berkelanjutan. Terjemahan dari Outcome Document Transforming Our World: The 2030 Agenda For Sustainable Development. United Nations. (2015)

[3] Green-Campus, Smarter Sustainanble Campus Communities, A Guide for Campuses Embarking on the Green-Campus Programme. An Taisce, Environmental Education Unit. (2013)

[4] Vinod, A., and Venugopal, K. Environmental Studies. 1st ed. Calicut University Central Co-operative Stores, LTD No. 4347. (2010)

[5] Ifegbesan, A. Exploring secondary school students' understanding and practices of waste management in Ogun State, Nigeria. International Journal of Environment and Science Education, 5(2), pp. 201-215. (2010)

[6] Bagheri Ardabylyan M, Islami NA. Survey knowledge and attitudes of students at Zanjan University of Medicaciences about recycling and separation of solid waste. Hamedan: 10th National Conference on Environmental Health; (2007).

[7] Mazaheri Tehrani, A. and Hosseindoost, Gh. and Miranzadeh, M.B. Knowledge and Attitude Level of Students about Solid Waste Recycling; Kashan University of Medical Sciences. International Archives of Health Sciences, 3.K. Elissa, "Title of paper if known," unpublished. (2016)

[8] Ehrampoush MH, Moghadam MB. Survey of knowledge, attitude and practice of Yazd University of Medical Sciences students about solid wastes disposal and recycling. Iran J Environ Health Sci Eng. 2005;2(2):26-30. (2005) 